\title{
THE TREND AND INTEREST IN SPORTS CYCLING DURING THE COVID-19 PANDEMIC
}

\author{
Muhad Fatoni $^{1 *}$, Gatot Jariono ${ }^{1}$, Subroto ${ }^{1}$, Chandra Triadi ${ }^{1}$ \\ ${ }^{1}$ Program Studi Pendidikan Olahraga, Fakultas Keguruan dan Ilmu Pendidikan, Universitas Muhammadiyah \\ Surakarta, JL. A. Yani Tromol Pos 1, Pabelan Kartasura, Surakarta, Jawa Tengah, Indonesia \\ E-mail:*mf378@ums.ac.id,gj969@ums.ac.id
}

\begin{abstract}
The requirement for healthy breathing and maintaining body immunity defense is getting higher with the pandemic, mindfulness of the importance point of maintaining health and body immunity has become a new mindset approach in society. One of the efforts and hard works considered effective by the society to achieve realize in good physical nature and fit condition is by exercising. One of the sport that has many benefits is cycling. The perseverance of this study was to analyze trend and interest in society cycling during the pandemic. This research is quantitative descriptive. The research subjects were taken using purposive random sampling technique. The totally subjects studied in this study research were 130 people, which were divided into four groups (genres) of bicycles, namely BMX, Roadbike, Mountain Bike and Trial. In this research focuses in collected data. Data were collected using cross-sectional surveys using a Likert scale. The results of this research study are that there are 65 samples in the high category and get a percentage value of 50.00\%, 63 samples in the medium category get a percentage value of $48.46 \%$, and 2 samples in the less category get a percentage value of 1.54 . \%. Meanwhile, of the three types of bicycle genres that have the highest trend are road bikes with 62 respondents, then mountain bikes with 44 respondents, BMX and Trial with 12 respondents each. The conclusion of this study is that road bikes are the most trending genre among the public and the public interest in cycling during the Covid-19 pandemic is in the high category.
\end{abstract}

Keywords: Cycling, Roadbike, Mountainbike, BMX

\section{TREN DAN MINAT OLAHRAGA BERSEPEDA MASYARAKAT PADA MASA PANDEMI COVID-19}

\begin{abstract}
Abstrak
Tuntutan untuk hidup sehat dan menjaga imunitas tubuh semakin tinggi dengan adanya pandemi, kesadaran tentang pentingnya menjaga kesehatan dan imunitas tubuh menjadi mindset baru dalam masyarakat. Salah satu upaya yang dianggap efektif oleh masyarakat untuk mencapai kondisi sehat dan bugar adalah dengan berolahraga. Salah satu olahraga yang memiliki banyak manfaat adalah olahraga bersepeda. Tujuan penelitian ini adalah untuk menganalisis tren dan minat olahraga bersepeda masyarakat pada masa pandemi. Penelitian ini merupakan penelitian deskriptif kuantitatif. Subjek penelitian diambil menggunakan teknik purpossive random sampling. Total subjek yang diteliti dalam penelitian ini berjumlah 130 orang, yang terbagi menjadi empat kelompok (genre) sepeda, yaitu $B M X$, Roadbike, Mountain Bike dan Trial. Pengambilan data dilakukan dengan memakai metode crosssectional surveys menggunakan skala Likert. Hasil dari penelitian ini adalah ada 65 sampel memiliki minat yang tinggi dalam olahraga sepeda, dan dengan nilai presentase sebesar 50,00\%, 63 sampel memiliki minat yang sedang dalam olahraga bersepeda, dengan nilai presentase sebesar $48,46 \%$, dan 2 sampel dalam kategori minat rendah, dengan nilai presentase sebesar 1,54\%. Sementara itu dari ketiga jenis genre sepeda yang memiliki tren paling tinggi adalah roadbike dengan 62 responden, kemudian mountain bike dengan 44 responden, BMX dan Trial dengan masing-masing 12 responden. Kesimpulan dari penelitian ini adalah bahwa sepeda roadbike menjadi genre paling tren di kalangan masyarakat dan minat olahraga bersepeda masyarakat pada masa pandemi covid-19 dalam kategori tinggi.
\end{abstract}

Kata kunci : Sepeda, Roadbike, Mountainbike, BMX 


\section{PENDAHULUAN}

Kesehatan dan kebugaran merupakan sesuatu yang mahal pada era modern seperti sekarang ini. Kondisi sosial masyarakat modern yang sibuk dengan berbagi aktivitas konsumtif akibat gaya kapitalisme baru yang di besarkan oleh teknologi turut memperparah kondisi tersebut (Permana, 2012), sehingga kegiatan yang bersifat untuk menjaga kebugaran tubuh urung dilakukan, sehingga dalam sebuah penelitian disebutkan secara umum masyarakat Indonesia tergolong masyarakat yang kurang aktif (Auguntari et al., 2018). Pandemi covid-19 yang masuk ke Indonesia pada awal tahun 2020 membuat keadaan tersebut berbalik, kesibukan pekerjaan dan aktivitas masyarakat yang mulanya dilakukan diluar rumah, kini harus dialihkan ke dalam rumah (Langheinrich, 2020). Intensitas pekerjaan yang biasa dilakukan oleh masyarakat juga mengalami pengurangan. Adanya pembatasan sosial dari pemerintah lokal dan nasional dalam rangka penanganan wabah agar tidak semakin meluas membuat semua aktivitas yang menjadi rutinitas masyarakat berubah baik ritme maupun intensitasnya. Perubahan kondisi tersebut membuat masyarakat benar-benar harus adaptif dengan keadaan tersebut. Adanya idiom baru "work from home" (bekerja dari rumah) mengharuskan masyarakat hanya boleh melakukan aktifitas pekerjaan sehari-hari dari rumah (Bick et al., 2020). Tuntutan untuk hidup sehat dan menjaga imunitas tubuh semakin tinggi (Handayani et al., 2020) dengan adanya pandemi.

Salah satu upaya yang dianggap efektif oleh masyarakat untuk mencapai kondisi sehat dan bugar adalah dengan berolahraga (Williams et al., 2017). Naluri manusia yang senantiasa untuk selalu bermain (homo ludens) dan bergerak (homo se movens) turut mempengaruhi perkembangan olahraga di dunia (Sapto Adi, 2001). Secara umum, setiap individu memiliki kebutuhan untuk sehat secara fisik maupun mental. Kesehatan merupakan syarat mutlak tercapainya produktivitas kerja, dan olahraga merupakan salah satu sarana untuk memperoleh kebugaran dan kapasitas fisik optimal (Saputri \& Indra, 2016). Olahraga dapat melahirkan kesenangan dan hiburan bagi pelaku olahraga (Palar et al., 2015). Penelitian sebelumnya mengatakan bahwa, remaja yang terbiasa melakukan aktivitas fisik secara rutin, memiliki potensi rendah untuk depresi dan rasa cemas, dan terhindar dari kecenderungan melakukan perilaku buruk sosial dibanding dengan temannya yang kurang aktif (Kirkcaldy et al., 2002). Kurang lebih $60 \%$ hasil penelitian melaporkan bahwa, orang yang berpartisipasi dalam aktivitas fisik dapat meningkatkan level self esteem (McAuley et al., 2005). Dengan melakukan aktifitas fisik atau berolahraga maka tubuh akan mendapatkan berbagai manfaat (Yildiz, 2012). Salah satu olahraga yang memiliki banyak manfaat adalah olahraga bersepeda. Selain banyak manfaat, olahraga bersepeda juga banyak digemari oleh masyarakat. (Priego Quesada et al., 2019) menyatakan bahwa bersepeda adalah olahraga populer di seluruh dunia yang telah terbukti tidak hanya meningkatkan kebugaran dan kesehatan, tetapi juga membantu proses rehabilitasi karena impact yang lebih rendah terhadap persendian dibandingkan dengan kegiatan lain seperti berjalan dan berlari.

Kegemaran masyarakat terhadap olahraga bersepeda terus meningkat dengan adanya pandemi covid-19 (Hong et al., 2020). Olahraga bersepeda dipilih oleh masyarakat karena memiliki daya tarik tersendiri, selain memiliki banyak pilihan genre. Bersepeda adalah salah satu bentuk aktivitas gerak manusia yang paling efisien yang membutuhkan lebih sedikit energi pada system sendi daripada transportasi darat lainnya (Thompson et al., 2020). Selain itu olahraga bersepeda dan aerobik juga mampu menurunkan persentase lemak tubuh dan berat badan (Penggalih \& Niamila, 2015; Yuniana, 2020). Berdasarkan jenisnya (genre) olahraga bersepeda dibedakan menjadi tiga kelompok besar yaitu BMX, Roadbike, Mounrain Bike dan Trial (Union Cycliste Internationale (UCI), n.d.). BMX adalah singkatan dari Bicycle MotoCross jenis sepeda ini diperlombakan dalam sirkuit khusus, dengan model lintasan berupa tikungan tajam dan gunungan bergelombang, yang membutuhkan tingkat keseimbangan dan kemampuan handling yang baik serta kemampuan mengayuh pedal dengan cepat, perlombaan 
BMX dilakukan dengan waktu singkat antara 30-40 detik dalam satu race balap (Elvira et al., 2020) dibutuhkan skill khusus untuk menekuni genre sepeda ini, berbeda dengan roadbike, bersepeda menggunakan jenis sepeda roadbike banyak dilakukan oleh kaum urban perkotaan, sebagai rutinitas untuk mengisi waktu luang untuk sekedar berjumpa dengan teman sesama atau antar komunitas atau bepergian untuk tujuan rekreasi melintasi jalan raya (Sirna, 2016). Selain itu pada genre roadbike juga terdapat kelas lomba, biasanya dilakukan dengan jarak tempuh tertentu, sehingga kemampuan daya tahan atlet sangat penting dalam lomba sepeda diajalan raya. Sementara itu jenis sepeda mountain bike memilki lebih banyak nomor lomba, ada nomor Cross-country, Enduro, Downhill, dan nomor pengembangan lain dari ketiga kelas lomba tersebut. Masing-masing kelas lomba dari sepeda ini memilki jenis track dan lintasan yang berbeda (Hagen \& Boyes, 2016). Biasanya penggolongan tingkat kesulitan track didasarkan pada tinggi travel suspensi sepeda. Semakin tinggi atau panjang travel suspensi sepeda maka peruntukan lintasannya akan semakin ekstrim dan sulit. Jenis sepeda gunung level yang paling menantang adalah downhill. Dengan model lintasan ekstrim, dengan berbagai halang rintang mulai dari akar, batu, dan drop. Untuk tampil baik, pebalap top perlu berada dalam kondisi fisik puncak dan bisa menghafal rintangan di lintasan balap. Diperlukan jumlah energi yang luar biasa dalam satu balapan (Macdermid \& Morton, 2012).

Bersepeda menjadi kegiatan dengan tingkat partisipasi yang tinggi dan semakin popular (Hong et al., 2020). Dalam beberapa waktu terakhir ini bersepeda telah berubah status dari olahraga elit Eropa menjadi olahraga partisipasi massa di seluruh dunia (Visentini, 2017). Hal ini salah satu dipengaruhi oleh ditayangkannya berbagai perlombaan sepeda lintas negara, yang secara rutin dan teratur (Macdermid \& Morton, 2012). Proses pengembangan sebuah cabang olahraga dilakukan dengan teori duplikasi, dengan prinsip penggemar. Semakin banyak penggemar maka sebuah cabang olahraga akan cepat berkembang begitu juga dengan industrinya, akan semakin maju dan menghasilkan profit yang tinggi (Yoshida et al., 2015).

Secara teoritis, minat adalah penerimaan atau hubungan antara diri sendiri dengan sesuatu yang berada diluar dirinya (Djaali, 2008), sedangkan (Kardi, 2019) mendefinisikan minat adalah keinginan yang ada pada diri seseorang yang mendorong orang tersebut untuk berusaha mencapai suatu standar keunggulan. Selaras dengan pernyataan tersebut, (Slameto, 2003) menyatakan bahwa minat adalah suatu rasa suka dan tertarik tanpa ada yang menyuruh pada suatu hal atau aktivitas. Minat berolahraga dipengaruhi oleh kebutuhan akan keterkaitan hubungan interpersonal, hubungan intim, dan sosial, serta merasa puas terhadap rasa kebersamaan atau persahabatan, atau mengembangkan hubungan dekat dengan orang lain (Ryan \& Deci, 2020). Pada aspek yang lain, minat dan loyalitas penggiat olahraga memilki peranan penting untuk pengembangan industri olahraga (Da Silva \& Las Casas, 2017).

(Wann, 1995) memperkenalkan Sport Fan Motivation Scale (SFMS), yang di dalamnya mencakup kategorisasi delapan motivasi: eustress; manfaat harga diri; melarikan diri dari kehidupan sehari-hari; hiburan; faktor-faktor ekonomi; kualitas estetika; afiliasi kelompok; dan, kebutuhan keluarga. Demikian pula, (Milne \& McDonald, 1999) mengusulkan skala Motivasi untuk Konsumen Olahraga (MSC), yang terdiri dari dua belas konstruksi motivasi: pengambilan risiko; pengurangan stres; agresi; afiliasi; fasilitas sosial; harga diri; kompetisi; prestasi; penguasaan keterampilan; estetika; pengembangan nilai; aktualisasi diri. Selanjutnya (Trail \& James, 2001) mengembangkan Skala Motivasi untuk Konsumsi Olahraga (MSSC). MSSC mengukur sembilan motif: pencapaian; akuisisi pengetahuan; estetika; drama / eustress; melarikan diri; keluarga; daya tarik fisik peserta; kualitas ketrampilan fisik peserta; dan, interaksi sosial.

(Zhang et al., 2001) mengadopsi kategorisasi asli (Sloan, 1989) dan mengembangkan Skala Motivasi Kehadiran (SAM). Para sarjana ini meneliti hubungan antara faktor sosiomotivasi (stres dan hiburan, pencarian prestasi, katarsis dan agresi, efek menyehatkan, dan citra komunitas) dan kehadiran di pertandingan hoki liga kecil. Mereka menyimpulkan bahwa dari 
lima teori utama yang diajukan oleh Sloan, tiga (efek menyehatkan, pencarian prestasi dan hiburan) relevan dengan kehadiran.

\section{METODE}

Penelitian ini merupakan penelitian deskriptif kuantitatif. Subyek penelitian ini adalah masyarakat pelaku olahraga bersepeda yang ada di Kota Surakarta. Subjek penelitian diambil menggunakan teknik purpossive random sampling, dengan kriteria sampel antara lain aktif di komunitas sepeda, menekuni olahraga sepeda minimal 1 tahun, usia rata-rata sampel 20 tahun, dan berdomisili di Surakarta. Total subjek yang diteliti dalam penelitian ini berjumlah 130 orang, yang terbagi menjadi empat kelompok (genre) sepeda, yaitu BMX, Roadbike, Mountain Bike dan Trial.

Instrumen pengambilan data yang dipakai dalam penelitian ini adalah angket kuesioner yang memuat kisi-kisi yang terkait dengan aktivitas, dorongan, dan hambatan yang mungkin dialami oleh subjek penelitian. Selanjutnya kisi-kisi tersebut disusun dan diujikan pada subjek lain diluar subjek penelitian untuk memastikan bahwa kuesioner yang dibuat memenuhi kelayakan untuk digunakan dalam penelitian (valid dan reliabel). Kuesioner diadopsi dari Sport Motivation Scale (Pelletier et al., 1995), dengan metode cross-sectional surveys, yang dikemas dalam bentuk elektronik kuesioner sehingga dapat diakses secara bersamaan oleh subyek. Kuesioner dikuantifikasikan menggunakan Skala Likert.

Kuesioner yang digunakan untuk pengambilan data tren dan minat olahraga bersepeda diuji reabilitasnya untuk mengetahui tingkat kelayakan kuesioner. Hasil uji reliabilitas menunjukkan nilai alpha cronbach sebesar 0,92 dengan nilai $r>0,176$ sehingga kuesioner dianggap reliabel dan layak untuk digunakan sebagai instrumen penelitian

Data utama berupa hasil kuisioner tren dan minat olahraga bersepeda. Data-data tersebut dikumpulkan secara langsung oleh peneliti, sehingga peneliti merupakan instrumen utama. Sebelum digunakan, kuisioner divalidasi terlebih dulu oleh validator yang memiliki kompetensi di bidang olahraga bersepeda.

Tahapan yang terakhir yakni menentukan nilai prosentase minat untuk setiap indikator. Nilai pada tiap indikator kemudian dapat diterjemahkan dalam bentuk kalimat kualitatif dengan deskripsi sebagai berikut:

Tabel 1. Kriteria angket minat tiap indikator

\begin{tabular}{ccc}
\hline No & Persentase & Kategori \\
\hline 1 & $76 \%-100 \%$ & Baik \\
2 & $56 \%-75 \%$ & Cukup \\
3 & $41 \%-55 \%$ & Kurang Baik \\
4 & $0 \%-40 \%$ & Tidak Baik \\
\hline \multicolumn{2}{c}{ (Arikunto, 2014) }
\end{tabular}

\section{HASIL DAN PEMBAHASAN}

Data empiris yang diperoleh melalui angket tren dan minat olahraga bersepeda masyarakat Kota Surakarta pada masa pandemi covid-19 terhadap empat komunitas bersepeda yaitu BMX, mountain bike, road bike, dan trial berjumlah 130 orang, dengan rincian jumlah responden sebagai berikut: BMX berjumlah 12 orang, mountain bike berjumlah 44 orang, road bike berjumlah 62 orang, dan trial berjumlah 12 orang. Hasil Analisis tren dan minat olahraga bersepeda komunitas bersepeda yaitu BMX, mountain bike, road bike, dan trial pada masa pandemi covid-19 dalam kategori tinggi, hal ini dibuktikan dari angket yang telah disebarkan melalui google formulir dari 130 sampel komunitas bersepeda yaitu BMX, mountain bike, road bike, dan trial diketahui ada 65 sampel berada pada kategori tinggi dan memperoleh nilai presentase sebesar 50,00\%, 63 sampel berada pada kategori sedang memperoleh nilai presentase sebesar $48,46 \%$, dan 2 sampel dalam kategori kurang memperoleh nilai presentase sebesar 1,54\%. Dengan demikian dapat ditarik suatu kesimpulan bahwa tren dan minat olahraga 
MEDIKORA, Vol. 20 No. 1 April 2021 - 88

Muhad Fatoni, Gatot Jariono, Subroto, Chandra Triadi

bersepeda komunitas bersepeda yaitu BMX, mountain bike, road bike, dan trial pada masa pandemi covid-19 dalam kategori tinggi.

Tabel 2. Rekapitulasi hasil analisis deskriptif data penelitian

\begin{tabular}{llcc}
\hline No & Kategori & Jumlah sampel & Persentase (\%) \\
\hline 1 & Tinggi & 65 & $50.00 \%$ \\
2 & Sedang & 63 & $48.46 \%$ \\
3 & Rendah & 2 & $1.54 \%$ \\
& Jumlah & 130 & $100 \%$ \\
\hline
\end{tabular}

Berdasarkan hasil analisis deskriptif frekuensi diatas, berikut ini disajikan data tren dan minat olahraga bersepeda Kota Surakarta pada masa pandemi covid-19 dalam bentuk histogram berikut:

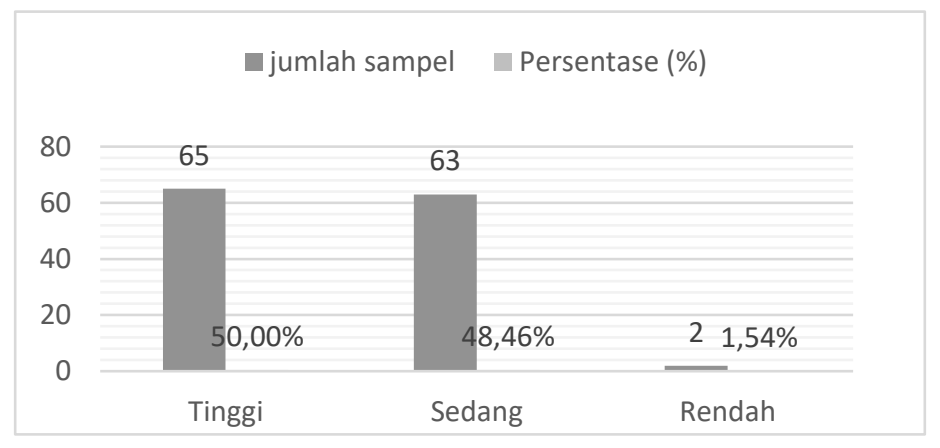

Gambar 1. Histogram data skor hasil tren dan minat olahraga bersepeda masyarakat Kota Surakarta pada masa pandemi covid-19

Berdasarkan data yang diperoleh dari penelitian tentang analisis tren dan minat olahraga bersepeda Kota Surakarta pada masa pandemi covid-19 dalam kategori tinggi. Digambarkan pada setiap indikator dan sub indikator penyataan dalam nilai persentase pernyataan angket tren dan minat olahraga bersepeda Kota Surakarta pada masa pandemi covid-19, dari masingmasing komunitas yang terdiri dari komunitas bersepeda yaitu BMX, mountain bike, road bike, dan trial dalam kategori tinggi. Hal ini dibuktikan dari angket yang telah disebarkan melalui google formulir dari 130 sampel komunitas bersepeda yaitu BMX, mountain bike, road bike, dan trial diketahui ada 65 sampel berada pada kategori tinggi dan memperoleh nilai presentase sebesar 50,00\%, 63 sampel berada pada kategori sedang memperoleh nilai presentase sebesar $48,46 \%$, dan 2 sampel dalam kategori kurang memperoleh nilai presentase sebesar 1,54\%.

Tren dan minat olahraga bersepeda Kota Surakarta pada masa pandemi covid-19 diperoleh hasil bahwa fenomenologi pandemi covid-19 dalam berolahraga dan aktivitas fisik dipengaruhi oleh motivasi baik dari dalam maupun di luar diri seseorang dalam melakukan aktivitas fisik (Jariono \& Subekti, 2020). Hal ini sejalan yang dikemukakan oleh (Blegur \& Mae, 2018) minat merupakan penentu perilaku individu yang timbul dari energi dan kekuatan internal, sehingga mempengaruhi cara berpikir, cara merasa, dan cara berinteraksi individu dengan yang lainnya. Hal ini sejalan dengan (Anam et al., 2016) dalam olahraga secara implisit disebutkan bahwa motivasi merupakan prasyarat penting bagi seorang atlet untuk berprestasi, karena dengan motivasi tekanan dan stress bisa teratasi, selain itu dengan motivasi performa atlet dapat terjaga.

Minat olahraga masyarakat Kota Surakarta pada masa pandemi ini khususnya olahraga bersepeda meningkat drastis (Mulato Isha'an, 2020). Dilapangan hal tersebut dibuktikan dengan bertambahnya pelaku olahraga bersepeda, hampir di setiap ruas jalan kota Surakarta. Bahkan dibeberapa toko sepeda ternama di Surakarta membatasi jumlah pembelian unit sepeda 
untuk menjaga ketersediaan stok (Mulato Isha'an, 2020). Tren tersebut turut menaikkan keuntungan penjualan sepeda yang melonjak hingga tiga kali lipat atau 300\% walaupun harganya naik 15\% (rzy, 2020). Fenomena ini tentunya dipengaruhi oleh kondisi global yang sama-sama mengalami perubahan kebiasaan karena efek pandemi (Hong et al., 2020)

Hal ini dikuatkan dengan beberapa laporan penelitian dari penelitian serupa, dengan judul Motivasi dan Minat Masyarakat dalam Berolahraga Sepeda di Kota Semarang (Romadhon \& Rustiadi, 2016), dari hasil analisis data yang dilakukan mayoritas orang dalam melakukan olahraga sepeda memiliki motivasi dengan kategori baik sebanyak 34 orang dari total 62 sampel, sementara dengan kategori sangat baik, 28 orang dari 62 sampel, dan tidak ada orang dalam kategori kurang baik atau kurang. Kesimpulan bahwa mayoritas sampel masyarakat yang berolahraga sepeda di Kota Semarang dominan masuk dalam kategori baik. Hasil tersebut menunjukkan bahwa baik dari segi minat maupun motivasi berada dalam kategori baik.

Dalam penelitian yang lain dengan judul Survei Minat dan Motivasi Masyarakat Untuk Bersepeda pada Pelaksanaan "Jogja Last Friday Ride" Di Kota Yogyakarta (Pranata, 2016) juga menyebutkan hal yang serupa. Hasil penelitian ini menunjukan 50\% masyarakat memiliki minat yang sangat tinggi, $48 \%$ termasuk dalam kriteria tinggi, $2 \%$ termasuk dalam kategori sedang.

\section{SIMPULAN}

Minat masyarakat dalam olahraga sepeda didasarkan pada dorongan yang dimiliki seperti keinginan untuk hidup sehat, menambah relasi, hiburan dan gaya hidup, sehingga dapat mempengaruhi tren. Pengalaman afektif yang didapatkan ketika melakukan olahraga mampu meningkatkan minat seseorang untuk terus terlibat dan mengulang kegiatan yang bersifat rekreasi luar ruangan (Hagen \& Boyes, 2016) seperti bersepeda. Sepeda roadbike menjadi tren paling tinggi pada masyarakat Surakarta sebagai sarana menyalurkan dorongan tersebut ditengah pandemi covid-19. Sepeda roadbike dipilih oleh masyarakat karena memiliki kemudahan dalam penggunaan dan perawatan. Melakukan olahraga bersepeda dengan sepeda roadbike bisa dilakukan dimana saja tanpa membutuhkan sirkuit/trek khusus, sehingga pertimbangan ini yang membuat masyarakat memilih sepeda roadbike. Sementara itu mountain bike menempati urutan kedua dalam hal tingkat peminat, faktor yang mempengaruhi kondisi tersebut salah satunya adalah gaya hidup dan passion masyarakat. Beberapa jenis sepeda mountain bike memerlukan lintasan khusus di daerah pegunungan, walaupun bisa digunakan di jalan raya namun perbedaan geometri dan spesifikasi sepeda membuat sepeda gunung tidak efektif digunakan dijalan raya, membuat hal ini menjadi pertimbangan tersendiri bagi masayarakat. Sedangkan minat masyarakat Surakarta terhadap olahraga sepeda secara keseluruhan masuk dalam kategori tinggi dengan nilai persentase sebesar $61,21 \%$. Tingginya minat masyarakat terhadap olahraga sepeda menjadi indikator yang baik terhadap tingginya kesadaran masyarakat untuk berolahraga dan hidup sehat. Artinya minat yang tinggi pada masyarakat Surakarta tersebut turut mempengaruhi tren tingginya pembelian sepeda. Sementara itu berubahnya olahraga bersepeda menjadi tren baru, menghasilkan peluang dibidang industri, seperti industri pembuatan baju dan perlengkapan sepeda, penyediaan jasa reparasi sepeda, penjualan sparepart, dan pengembangan tempat wisata sepeda (bike park).

\section{DAFTAR PUSTAKA}

Anam, M., Mexitalia, M., Widjanarko, B., Pramono, A., Susanto, H., \& Subagio, H. W. (2016). Pengaruh Intervensi Diet dan Olah Raga Terhadap Indeks Massa Tubuh, Lemak Tubuh, dan Kesegaran Jasmani pada Anak Obes. Sari Pediatri. https://doi.org/10.14238/sp12.1.2010.36-41

Arikunto, S. (2014). Prosedur Penelitian: Suatu Pendekatan Penelitian. In Rineka Cipta. 
Auguntari, I. T., Ray, H. R. D., \& N, N. (2018). Aktivitas Fisik High Intensity Intermittent Exercise (HIIE): Antara Obesitas dan Self Esteem. Jurnal Pendidikan Jasmani Dan Olahraga. https://doi.org/10.17509/jpjo.v3i1.9733

Bick, A., Blandin, A., \& Mertens, K. (2020). Work from Home After the COVID-19 Outbreak. Federal Reserve Bank of Dallas, Working Papers. https://doi.org/10.24149/wp2017r1

Blegur, J., \& Mae, R. M. (2018). Motivasi berolahraga atlet atletik dan tinju. Jurnal Keolahragaan. https://doi.org/10.21831/jk.v6i1.16150

Da Silva, E. C., \& Las Casas, A. L. (2017). Sport fans as consumers: An approach to sport marketing. British Journal of Marketing Studies, 5(4), 36-48.

Djaali, H. (2008). Psikologi pendidikan. Jakarta: Bumi Aksara, 138.

Elvira, J. L. L., Mateo-March, M., Zabala, M., \& Blasco-Lafarga, C. (2020). The use of accelerometry to evaluate the BMX cycling starting hill. Effect of the Q-Ring ${ }^{\mathrm{TM}}$ on the acceleration profile. Sports Biomechanics, 1-15. https://doi.org/10.1080/14763141.2020.1770323

Hagen, S., \& Boyes, M. (2016). Affective ride experiences on mountain bike terrain. Journal of Outdoor Recreation and Tourism, 15, 89-98.

Handayani, R. T., Arradini, D., Darmayanti, A. T., Widiyanto, A., \& Atmojo, J. T. (2020). Pandemi covid-19, respon imun tubuh, dan herd immunity. Jurnal Ilmiah Stikes Kendal.

Hong, J., McArthur, D., \& Raturi, V. (2020). Did safe cycling infrastructure still matter during a COVID-19 lockdown? Sustainability (Switzerland). https://doi.org/10.3390/su12208672

Jariono, G., \& Subekti, N. (2020). Sports Motivation Survey And Physical Activity Students Of Sport Education Teacher Training And Education Faculty FKIP Muhammadiyah University Surakarta. Kinestetik: Jurnal Ilmiah Pendidikan Jasmani. https://doi.org/10.33369/jk.v4i2.12449

Kardi, I. S. (2019). Psychological Skill Characteristics of Athletics, Weightlifting, Cycling, Swimming, and Waterskiing Athletes based on 2017 SEA Games Medal Achievements. Jurnal Pendidikan Jasmani Dan Olahraga. https://doi.org/10.17509/jpjo.v4i1.12452

Kirkcaldy, B. D., Shephard, R. J., \& Siefen, R. G. (2002). The relationship between physical activity and self-image and problem behaviour among adolescents. Social Psychiatry and Psychiatric Epidemiology. https://doi.org/10.1007/s00127-002-0554-7

Langheinrich, M. (2020). The New Normal. In IEEE Pervasive Computing. https://doi.org/10.1109/MPRV.2020.3032048

Macdermid, P. W., \& Morton, R. H. (2012). A longitudinal analysis of start position and the outcome of World Cup cross-country mountain bike racing. Journal of Sports Sciences, 30(2), 175-182. https://doi.org/10.1080/02640414.2011.627368

McAuley, E., Elavsky, S., Motl, R. W., Konopack, J. F., Hu, L., \& Marquez, D. X. (2005). 
Physical activity, self-efficacy, and self-esteem: Longitudinal relationships in older adults. Journals of Gerontology - Series B Psychological Sciences and Social Sciences. https://doi.org/10.1093/geronb/60.5.P268

Milne, G. R., \& McDonald, M. A. (1999). Sport marketing: Managing the exchange process. Jones \& Bartlett Learning.

Mulato Isha'an. (2020). Tren Sepedaan di Solo, Penjualan Melonjak. Radio Republik Indonesi.

Palar, C. M., Wongkar, D., \& Ticoalu, S. H. R. (2015). Manfaat latihan olahraga aerobik terhadap kebugaran fisik manusia. Jurnal E-Biomedik. https://doi.org/10.35790/ebm.3.1.2015.7127

Pelletier, L. G., Tuson, K. M., Fortier, M. S., Vallerand, R. J., Briere, N. M., \& Blais, M. R. (1995). Toward a new measure of intrinsic motivation, extrinsic motivation, and amotivation in sports: The Sport Motivation Scale (SMS). Journal of Sport and Exercise Psychology, 17(1), 35-53.

Penggalih, M. H. S. T., \& Niamila, I. (2015). Perbedaan perubahan lemak tubuh dan berat badan atlet balap sepeda pada berbagai intensitas latihan. Medikora, 14(2).

Permana, A. (2012). Gejala Alienasi dalam Masyarakat Konsumeristik. Jurnal Pemikiran Sosiologi, 1(2), 91-107.

Pranata, A. Y. (2016). Survei Minat dan Motivasi Masyarakat Untuk Bersepeda Pada Pelaksanaan "Jogja Last Friday Ride" di Kota Yogyakarta. Universitas Negeri Semarang.

Priego Quesada, J. I., Kerr, Z. Y., Bertucci, W. M., \& Carpes, F. P. (2019). A retrospective international study on factors associated with injury, discomfort and pain perception among cyclists. PloS One, 14(1), e0211197.

Romadhon, S. A., \& Rustiadi, T. (2016). Motivasi dan Minat Masyarakat Dalam Berolahraga Sepeda di Kota Semarang. ACTIVE: Journal of Physical Education, Sport, Health and Recreation, 5(1), 24-28.

Ryan, R. M., \& Deci, E. L. (2020). Intrinsic and extrinsic motivation from a self-determination theory perspective: Definitions, theory, practices, and future directions. Contemporary $\begin{array}{lll}\text { Educational Psychology, } & 61860 .\end{array}$ https://doi.org/https://doi.org/10.1016/j.cedpsych.2020.101860

rzy. (2020). Gowes Kembali Tren, Penjualan Sepeda di Solo Meroket 300\%. Okezone.Com. https://economy.okezone.com/read/2020/06/06/320/2225483/gowes-kembali-trenpenjualan-sepeda-di-solo-meroket-300

Sapto Adi, M. (2001). Sosiologi Olahraga (Jurusan Ilmu Keolahragaan Fakultas Ilmu Pendidikan (Ed.)). Universitas Negeri Malang.

Saputri, M. P. E., \& Indra, E. N. (2016). Minat Karyawan RS Bethesda untuk Menggunakan Fasilitas Olahraga Di Gym And Aerobic Rs Bethesda. Medikora, 15(2), 98-113. 
Sirna, K. M. (2016). Road Cycling Over Forty: Fitness, Friends, and Fondos. Sociology of Sport Journal, 33(3), 230-239.

Slameto. (2003). Belajar dan Faktor-faktor yang Mempengaruhinya. In Jakarta. PT. Rineka Cipta. Alfabeta.

Sloan, L. R. (1989). The motives of sports fans. Sports, Games, and Play: Social and Psychological Viewpoints, 2, 175-240.

Thompson, R. L., Gardner, J. K., Zhang, S., \& Reinbolt, J. A. (2020). Lower-limb joint reaction forces and moments during modified cycling in healthy controls and individuals with knee osteoarthritis. Clinical Biomechanics, 71, 167-175.

Trail, G. T., \& James, J. D. (2001). The motivation scale for sport consumption: Assessment of the scale's psychometric properties. Journal of Sport Behavior, 24(1).

Union Cycliste Internationale (UCI). (n.d.). Www.Uci.Org. Retrieved January 21, 2021, from https://www.uci.org

Visentini, P. (2017). A systematic review of parameters related to cycling overuse injuries or pain. Journal of Science and Medicine in Sport, 20, e69-e70.

Wann, D. L. (1995). Preliminary validation of the sport fan motivation scale. Journal of Sport and Social Issues, 19(4), 377-396.

Williams, M., Anderson, D., \& Rawson, E. (2017). Nutrition for Health, Fitness \& Sport. In McGraw Hill.

Yildiz, S. M. (2012). Instruments for measuring service quality in sport and physical activity services. Collegium Antropologicum, 36(2), 689-696.

Yoshida, M., Heere, B., \& Gordon, B. (2015). Predicting behavioral loyalty through community: Why other fans are more important than our own intentions, our satisfaction, and the team itself. Journal of Sport Management, 29(3), 318-333.

Yuniana, R. (2020). Effect of aerobic and load exercises on body fat and lung vital capacity. MEDIKORA, 19(2), 82-97.

Zhang, J. J., Pease, D. G., \& Lam, E. T. C. (2001). Sociomotivational Factors Affecting Spectator Attendance at Minor League Hockey Games. Sport Marketing Quarterly, $10(1), 43-54$. 